\title{
Adenosine cardiac magnetic resonance: follow-up of patients with very high cardiovascular risk
}

\author{
Alberto Esteban-Fernández ${ }^{1 *}$, Isabel Coma-Canella ${ }^{1}$, Gorka Bastarrika-Aleman², Joaquín Barba-Cosials ${ }^{1}$, \\ Nahikari Salterain-Gonzalez', Pedro M Azcárte-Aguero ${ }^{1,2}$
}

From 18th Annual SCMR Scientific Sessions

Nice, France. 4-7 February 2015

\section{Background}

Stress cardiac magnetic resonance with adenosine (CMR-A) is a valid test to rule out myocardial ischaemia. We follow-up a cohort of patients with CMR-A due to suspected myocardial ischaemia, considering patients with very high cardiovascular risk.

\section{Methods}

We included all patients with CMR-A between June 2009 and November 2012, considering two groups: those with a very high cardiovascular risk (prior myocardial infarction or/and Diabetes mellitus) and the rest of the patients. The follow-up was done in outpatient cardiology clinic or by

Table 1 Characteristics of the patients with CMR-A to rule out myocardial ischaemia considering cardiovascular risk

\begin{tabular}{ccc}
\hline & High cardiovascular risk ( $\mathrm{n}=134)$ & Non-high cardiovascular risk ( $\mathrm{n}=105)$ \\
\hline Age-years old & $68.0 \pm 8.3$ & $63.8 \pm 11.8$ \\
\hline Diabetes mellitus-no (\%) & $93(69.4)$ & - \\
Basal glucose (mg/dL) & $125 \pm 41$ & $103 \pm 33$ \\
HbA1c (\%) & $7.0 \pm 1.4$ & $6.1 \pm 1.3$ \\
\hline No tobacco history-no (\%) & $48(35.8)$ & $55(52.4)$ \\
\hline Arterial hypertension-no (\%) & $97(72.4)$ & $69(65.7)$ \\
\hline Dyslipidaemia-no (\%) & $104(77.6)$ & $53(50.5)$ \\
\hline BMl (kg/m2) & $29.8 \pm 6.1$ & $27.1 \pm 4.7$ \\
\hline Previous ictus-no (\%) & $12(9.0)$ & $4(3.1)$ \\
\hline Peripheral arterial disease-no (\%) & $7(6.7)$ \\
\hline Previous myocardial infarction-no (\%) & $33(24.6)$ & \\
PCl revascularization-no (\%) & $68(50.7)$ & - \\
CABG revascularization-no (\%) & $51(38.1)$ & $27(25.7)$ \\
\hline Result in CMR-A & $29(21.6)$ & $78(74.3)$ \\
Positive-no (\%) & - & $17(16 \%)$ \\
Negative-no (\%) & $56(41.8)$ & $5(4.8)$ \\
\hline Events in follow-up-no (\%) & $78(58.2)$ & $8(7.6)$ \\
ACS-no (\%) & $51(38.1)$ & $3(2.9)$ \\
Death for any cause-no (\%) & $21(15.7)$ & $1(1)$ \\
Admission for HF-no (\%) & $8(6)$ & \\
Revascularization-no (\%) & $2(1.5)$ & \\
\hline
\end{tabular}

${ }^{1}$ Cardiology Department, Clínica Universidad de Navarra, Pamplona, Spain

Full list of author information is available at the end of the article

(c) 2015 Esteban-Fernández et al; licensee BioMed Central Ltd. This is an Open Access article distributed under the terms of the Creative 

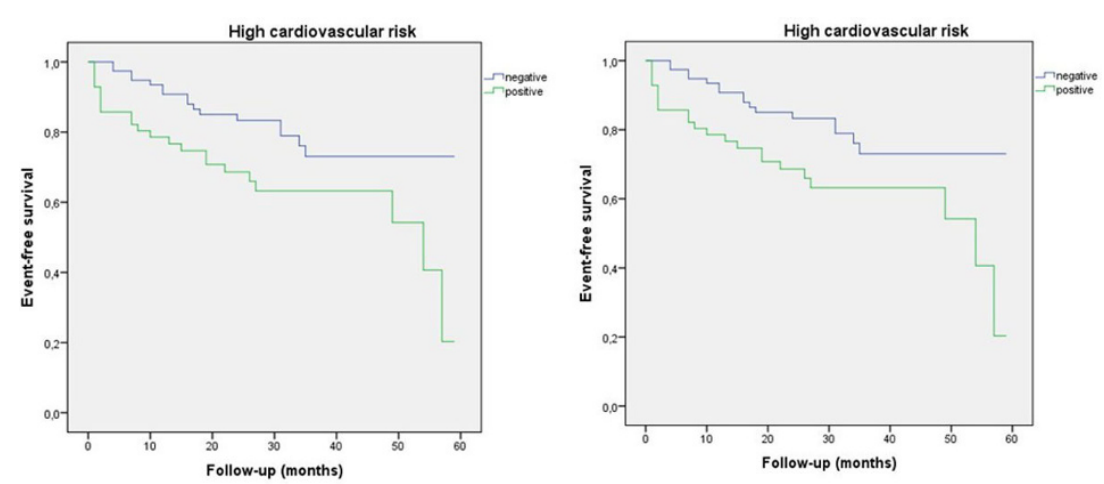

Figure 1

phone. We analyse free-event survival considering: acute coronary syndrome (ACS), death for any cause, admission for heart failure (HF) or necessity of revascularization as endpoints. The statistical analysis was made with SPSS 20.0.

\section{Results}

The follow-up of 239 patients (180 male) was done. 134 (56\%) were re-classified as high cardiovascular risk patients and 105 (44\%) as non-high cardiovascular risk ones. The basal characteristics of each group are summarize in table 1.

CMR-A was positive for myocardial ischaemia in 83 patients (35\%) and negative in $156(65 \%)$. The follow-up median was 25 months, with events in 68 patients. The results of the test and the events during the follow-up in each group are attached in table 1.

The analysis of Kaplan-Meier survival curves (1 and 2), considering the cardiovascular risk and the result of the test, showed statistical differences only in very high cardiovascular risk patients (Long Rank test; $\mathrm{p}=0.024$ ).

\section{Conclusions}

In this cohort of patients with very high cardiovascular risk, those with a negative result have fewer events in the follow-up. CMR-A allows a better classification of the global cardiovascular risk

\section{Funding}

There is not any funding to support this trial.

\section{Authors' details}

${ }^{1}$ Cardiology Department, Clínica Universidad de Navarra, Pamplona, Spain.

${ }^{2}$ Radiology Department, Clínica Universidad de Navarra, Pamplona, Spain.

Published: 3 February 2015
doi:10.1186/1532-429X-17-S1-P193

Cite this article as: Esteban-Fernández et al: Adenosine cardiac magnetic resonance: follow-up of patients with very high cardiovascular risk. Journal of Cardiovascular Magnetic Resonance 2015 17(Suppl 1):P193.
Submit your next manuscript to BioMed Central and take full advantage of:

- Convenient online submission

- Thorough peer review

- No space constraints or color figure charges

- Immediate publication on acceptance

- Inclusion in PubMed, CAS, Scopus and Google Scholar

- Research which is freely available for redistribution

Submit your manuscript at www.biomedcentral.com/submit 